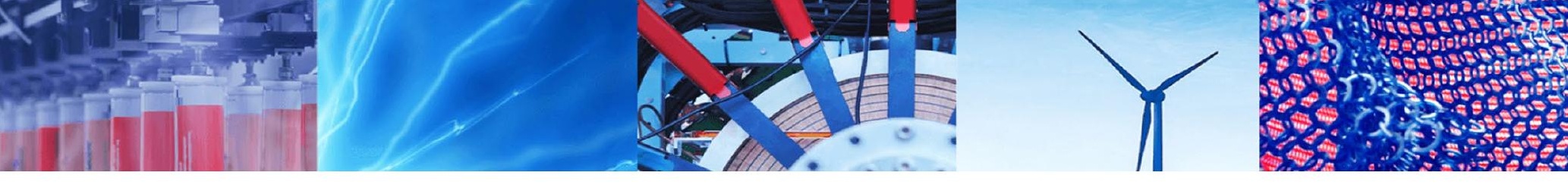

Research Article

\title{
Influence of the seasons on the water quality of the Marmeleiro River (Paraná, Brazil) using different bioindicators
}

\author{
Alessandra Suzin Bertan ${ }^{1}$. Anna Gabriela Drummond Xavier Teles ${ }^{1}$ - Bárbara Cunha Tesch de Oliveira ${ }^{1}$. \\ Lorrana Melo Ramalho Ferreira ${ }^{1} \cdot$ Nathana Andressa Thiel $^{2}$. Clarice Fieira ${ }^{3} \cdot$ Marilete Chiarelotto $^{4}$. \\ Fernando César Manosso ${ }^{5}$. Juan Carlos Pokrywiecki ${ }^{6} \cdot$ Ivane Benedetti Tonial $^{7}$. Ticiane Sauer Pokrywiecki ${ }^{6}$. \\ Elisângela Düsman ${ }^{7}$ (D)
}

Received: 25 March 2020 / Accepted: 3 October 2020 / Published online: 15 October 2020

(c) Springer Nature Switzerland AG 2020

\begin{abstract}
The use of environmental bioindicators and biomarkers has shown promising to evaluate water quality. In this study, the biological indicators Lactuca sativa L., Allium cepa L., and Artemia salina L. were used to verify the water quality of the Marmeleiro River (Paraná, Brazil). Water samples were collected at six points along the river, covering urban and rural areas over the four seasons. The experiment of germination and initial growth of the $A$. cepa seeds showed changes between seasons, but no difference between the collection points. Regarding L. sativa seeds, the results showed changes between the points and the seasons. In general, it was possible to correlate the highest numbers of germinated seeds, size of the germinated roots, percentage, and germination speed with the highest levels of phosphorus and lowest levels of chemical demand for oxygen, oils and greases, and total solids. The results of the cytotoxicity test with A. cepa showed an increase in the mitotic indices of Points 3 (spring, summer, and winter), 4 (spring and winter), 5, and 6 (summer and autumn) correlated with higher levels of phosphorus and chemical oxygen demand in water samples. For the immobility/mortality test with A. salina, in the spring and summer, all collection points were toxic, possibly due to the lower levels of dissolved oxygen in these samples. Therefore, bioindicators proved to be efficient to determine and monitor the Marmeleiro River toxicity and indicate that preservation actions should be implemented for this watershed.
\end{abstract}

Keywords Allium cepa L. A Artemia salina L. · Bioindicators · Lactuca sativa L. P Pollution · Water quality

Elisângela Düsman, edusman@utfpr.edu.br; Alessandra Suzin Bertan, alessandra.suzin.bertan@gmail.com;

Anna Gabriela Drummond Xavier Teles, annateles@alunos.utfpr.edu.br; Bárbara Cunha Tesch de Oliveira, barbaraoliveira@alunos.utfpr.edu.br; Lorrana Melo Ramalho Ferreira, lorranaf@hotmail.com; Nathana Andressa Thiel, nathana_94@hotmail.com; Clarice Fieira,

claricefieira@hotmail.com; Marilete Chiarelotto, meioambiente@marmeleiro.pr.gov.br; Fernando César Manosso, fmanosso@utfpr.edu.br; Juan Carlos Pokrywiecki, juan@utfpr.edu.br; Ivane Benedetti Tonial, ivane@utfpr.edu.br; Ticiane Sauer Pokrywiecki, ticiane@utfpr.edu.br | ${ }^{1}$ Academic of Chemical Engineering, Campus Francisco Beltrão, Universidade Tecnológica Federal do Paraná, Francisco Beltrão, Paraná, Brazil. ${ }^{2}$ Academic of Environmental Engineering, Campus Francisco Beltrão, Universidade Tecnológica Federal do Paraná, Francisco Beltrão, Paraná, Brazil. ${ }^{3}$ Master of the Post-Graduate Program in Environmental Engineering: Environmental Analysis and Technology, Campus Francisco Beltrão, Universidade Tecnológica Federal do Paraná, Francisco Beltrão, Paraná, Brazil. ${ }^{4}$ City Hall of Marmeleiro, Marmeleiro, Paraná, Brazil. ${ }^{5}$ Academic Department of Agricultural Sciences, Campus Francisco Beltrão, Universidade Tecnológica Federal do Paraná, Francisco Beltrão, Paraná, Brazil. ${ }^{6}$ Academic Department of Engineering, Campus Francisco Beltrão, Universidade Tecnológica Federal do Paraná, Francisco Beltrão, Paraná, Brazil. ${ }^{7}$ Academic Department of Chemistry and Biology, Campus Francisco Beltrão, Universidade Tecnológica Federal do Paraná, Cx. Postal 165, Francisco Beltrão, Paraná 85601-970, Brazil. 


\section{Introduction}

Each water resource has different features established by physicochemical, biological, and climate factors of the region [1], and the water quality should always be related to their predominant use, as this indicates the substances that it has possibly been in contact with it $[2,3]$.

The pollution classification distinguishes pollutants according to their origin, natural, industrial, urban, and agricultural-pastoral among others [2]. According to [4], there are several types of water pollution, such as biological, sedimentary, thermal, chemical, and radioactive. Chemical pollution is the most harmful.

The basin, even if it is preserved, can be impaired by soil infiltration resulted from precipitation. Also, human activity contributes to introducing harmful compounds to water quality, such as pesticides, industrial, and domestic waste dumps [5].

The water quality can be evaluated by several parameters, such as chemical, physical, and biological properties. According to [5], with the biological parameters, it is possible to analyze the potential of the water to transmit diseases and its toxicity. That way, biological tests have been used to monitor potentially toxic substances from the water.

Seeds of Lactuca sativa L. (lettuce), present themselves as a test organism used for ecotoxicological assessments in effluents and tributaries, thus serving as a good bioindicator of environmental quality [6, 7]. According to [8], the seeds of Allium cepa L. are also used as an indicator of public safety, because mutagenic substances can be identified through the use of this bioindicator. The $A$. cepa is an important test because it is an excellent in vivo model, where the roots grow in direct contact with the substances of interest, allowing to predict the DNA and cell cycle damage. In addition, the $A$. cepa test is one of the few targeted methods for measuring damage by accounting for chromosomal changes $[8,9]$, and the microcrustacean Artemia salina L. is found in saltwater and has been widely used in toxicity tests because it is easy to maintain in laboratory conditions and it is widely distributed. It has a worldwide dispersion and acts as a trophic link between planktonic communities and the upper chains [10].

According to [11], it is important to perform biomonitoring with more than one species and with different biomarkers to identify/compare how pollutants act in cells and organisms with varied metabolisms and cycles. Thus, the objective of this work was to evaluate and compare the influence of seasons on germination and initial growth of lettuce and onion seeds on the cytotoxicity of meristematic cells of $A$. cepa roots, and about the immobility/mortality of $A$. salina, exposed to the Marmeleiro River waters.

The Marmeleiro River is located at Marmeleiro city, the southwestern region of Paraná, and it is a tributary of the left bank of the Chopim River, which in turn is a sub-basin of the Iguassu River. The regions of the upper and middle thirds of the basin are characterized mainly by rural areas. At the beginning of the lower third, the main course goes through the urban area of Marmeleiro, urbanized and with crop regions. In the urban areas adjacent to the river, there are livestock, slaughterhouses, mechanical workshops, gas stations, associations, and the cemetery. Therefore, it is vital to check the quality of the water used in so many ways by the population of the municipality to identify the points or sources of pollution that are most clearly interfering in the bioindicators used so as to encourage the population's awareness of the need of taking care of water resources.

\section{Materials and methods}

\subsection{Treatment solution}

The Marmeleiro River water samples were collected at six points along its route, from the source to the mouth. Point 1, Source $\left(26^{\circ} 22^{\prime} 46^{\prime \prime} \mathrm{S}, 53^{\circ} 03^{\prime} 45^{\prime \prime}\right.$ W). Point 2, "Recanto Mata Nativa" (Native Forest Corner) beginning of the urban area $\left(26^{\circ} 09^{\prime} 39^{\prime \prime} \mathrm{S}, 53^{\circ} 01^{\prime} 34^{\prime \prime} \mathrm{W}\right)$. Point 3, Point of water collection to the Water Treatment Plant

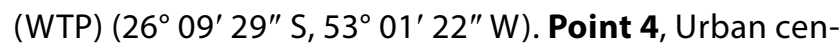
tral area of the city $\left(26^{\circ} 09^{\prime} 8^{\prime \prime} \mathrm{S}, 53^{\circ} 01^{\prime} 12^{\prime \prime} \mathrm{W}\right)$. Point 5, Point of treated effluent launching in the Sewage Treatment Plant (STP) ( $\left.26^{\circ} 08^{\prime} 57^{\prime \prime} \mathrm{S}, 53^{\circ} 01^{\prime} 8^{\prime \prime} \mathrm{W}\right)$. Point 6, River mouth ( $\left.26^{\circ} 05^{\prime} 46^{\prime \prime} \mathrm{S}, 52^{\circ} 59^{\prime} 10^{\prime \prime} \mathrm{W}\right)$, illustrated in the altimetric map and generalized hydrographic network of Fig. 1.

For the collection and preservation of the water samples, the methodologies described in Standard Methods [12] and NBR 9898 [13] were used. The samples were collected at the river banks approximately $2 \mathrm{~m}$ away and $1 \mathrm{~m}$ deep using a Van Dorn bottle (Alfakit). Global Positionings Systems (GPS) also were used to provide accurate sampling position data according to the selected points.

The samples were collected in December 2015 (late spring), March 2016 (late summer), June 2016 (late autumn), and September 2016 (late winter). Thus, it was possible to follow up the seasons' influence on the toxicity of the biomarkers and identify its impact on the thermal and/or chemical stratification and in the water column mixing [14]. 
Fig. 1 The Marmeleiro River basin and the six points of water collection. $\mathrm{P} 1$, river source, $\mathrm{P} 2$, the beginning of the urban area of the municipality, P3, the point of collection of water for the water treatment station, $\mathrm{P} 4$, the central urban area of the city (near the municipal cemetery), $P 5$, treated effluent released in sewage treatment station, and $\mathrm{P} 6$, river mouth

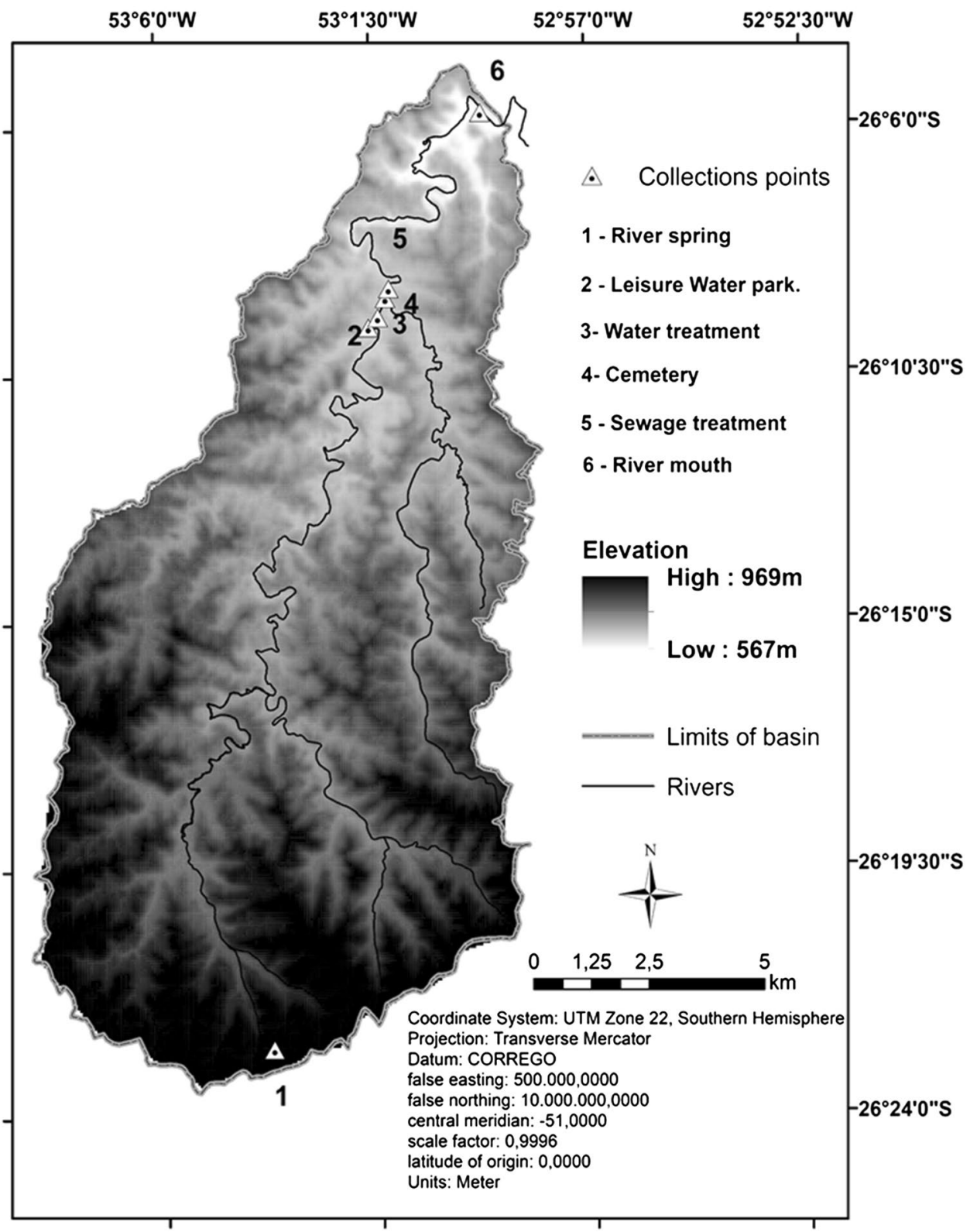

\subsection{Physicochemical parameters}

The physicochemical parameters analysis of the Marmeleiro River water samples followed the methodologies established by standard methods [12]. The parameters evaluated were $\mathrm{pH}$, chemical oxygen demand (COD), dissolved oxygen (DO), phosphorus, oils and greases, and total solids. The $\mathrm{pH}$ analysis was done using a bench $\mathrm{pH}$ meter (Tecnopon). The chemical oxygen demand was evaluated by the closed reflux method using the digestor block (Solab). The sample absorbance was read on the spectrophotometer UV-VIS (Thermo Scientific Model Helios Zeta). Hanna Instruments' model HI98186 meter was used for dissolved oxygen analysis. For the determination of total phosphorus, acid digestion was carried out followed by a colorimetry reaction (Spectrophotometer UV-VIS, Thermo Scientific Model Helios Zeta). The extraction of oil greases was carried out using Soxhlet extractors (Lucadema). The total solids were measured using a homogeneous portion of the sample and transferred quantitatively to a tared evaporation capsule, evaporated in a kiln at $110^{\circ} \mathrm{C}$ (Kiln for drying Model Luca-80/15).

\subsection{Germination and initial growth test with Allium cepa $\mathrm{L}$. and Lactuca sativa $\mathrm{L}$.}

The germination test with onion ( $A$. cepa) and lettuce ( $L$. sativa) seeds, acquired from local trade, was based on the methodology described by [15]. 
The tests were conducted in Petri dishes $(9 \mathrm{~cm}$ diameter) lined with filter paper (sterilized), dampened with a $5 \mathrm{~mL}$ sample from each collection point (P1-P6) of Marmeleiro River and $5 \mathrm{~mL}$ of distilled water (negative control$\mathrm{CO}-)$ or $5 \mathrm{~mL}$ of a solution of the cytotoxic agent methyl methanesulfonate $(0.016 \mathrm{uL} / \mathrm{mL} ;+\mathrm{CO})$. Each Petri dish was composed of 25 of onion/lettuce seeds randomized, with four replicates for each treated or control group.

After the assemblage, the dishes were wrapped with plastic film and remained at a constant temperature of $25^{\circ} \mathrm{C}$ and $12 \mathrm{~h}$ of photoperiod. The number of germinated seeds and the size of the roots were counted daily for 4 days, having the emergence of the radicle as a criterion for germination (3 $\mathrm{mm}$ root protrusion) [16].

From these data, the following calculations were carried out: number of seeds germinated per day, the average size of germinated roots per day, germination percentage (PG $=$ total number of germinated seeds $/ 25 \times 100)$, and germination rate $(\mathrm{VG}=$ the total number of germinated seeds/numbers of evaluation days), according to [17].

\subsection{Cytotoxicity test with Allium cepa L. meristematic cells}

The cytotoxicity test was carried out using $A$. cepa roots (onions), prepared by the Feulgen reaction, and stained with Schiff's reagent [18].

First, the onions' bulbs were cleaned and then placed in containers with mineral water at room temperature to generate the new roots (around 5 days). They were separated containing five onions for each control or treated group. Before the beginning of each treatment, two roots of each onion were collected to serve as a control of their bulbs $(0 \mathrm{~h})$. Then, the roots were exposed to the water samples from Marmeleiro River (Point 1-6), mineral water (negative control-CO-), and a solution of cyclophosphamide $(0.04 \mu \mathrm{g} / \mathrm{mL})$ (positive control-CO + ). After $24 \mathrm{~h}$ of treatment, two roots were collected $(24 \mathrm{~h})$ and the bulbs were placed again in mineral water for recovery for $24 \mathrm{~h}$ for the last collection ( $48 \mathrm{~h}$ ).

The collected roots were fixed in a solution of $5 \mathrm{~mL}$ ( 3 methanol: 1 acetic acid) and kept in the refrigerator for at least $24 \mathrm{~h}$. Next, the roots were washed twice in distilled water and exposed to $5 \mathrm{~mL}$ of hydrochloric acid $(\mathrm{HCl} 1 \mathrm{~N}$ at $60^{\circ} \mathrm{C}$ ) for $10 \mathrm{~min}$. Soon after, they were washed twice in distilled water and exposed to $5 \mathrm{~mL}$ of Schiff's reagent for $45 \mathrm{~min}$ in the dark, and then the meristematic region of the onions' roots was collected, stained with acetic orcein, and crushed to make the microscope slides.

The slides were analyzed using the blind test in a light microscope (40x). A thousand cells were counted from each onion and differentiating them according to the mitotic phases (Interphase, Prophase, Metaphase, Anaphase, and Telophase). To determine the percentage of the mitotic index (IM\%) of each sample of the evaluated groups, the following formula was used, Eq. (1).

$\mathrm{IM} \%=[($ number of dividing cells $) /$

$$
\text { (total number of analyzed cells) }] \times 100 \text {. }
$$

\subsection{Immobility/mortality test with Artemia salina L.}

The immobility/mortality test with the bioindicator Artemia salina $\mathrm{L}$. was done by the method proposed by [19] and [20].

Initially, cysts of $A$. salina were incubated in a solution of synthetic marine salt $(20 \mathrm{~g} / \mathrm{L})$ and aerated at a temperature of $25^{\circ} \mathrm{C}$ to induce their eclosion. After the eclosion, ten nauplii were transferred to test tubes containing $2 \mathrm{~mL}$ of water from different points of the Marmeleiro River, diluted in saline solution in $100 \%, 50 \%, 25 \%, 6.2 \%$, and $3.1 \%$ concentrations. The negative control (C-) group was prepared with $2 \mathrm{~mL}$ of saline solution. Triplicates were made of each sample group, and after $24 \mathrm{~h}$ the dead/immobile nauplii were counted.

\subsection{Statistical analysis}

The results of the physicochemical parameters were analyzed by the normality test and the analysis of variance (ANOVA), followed by the Tukey test $(n=3, a=0.05)$, and by the Action Stat program.

The number of seeds germinated per day, the average size of germinated roots per day, germination percentage, and germination rate were analyzed by the normality test and the ANOVA, followed by the Tukey test ( $n=4, a=0.05$ ), and by the Action Stat program.

The percentage of mitotic indices were analyzed by the ANOVA and the normality test, followed by the Tukey test $(n=5, a=0.05)$, and by the Action Stat program.

Mortality rates obtained with the experiment with $A$. salina were analyzed by the normality test and the ANOVA, followed by the Kruskal-Wallis test $(n=3, a=0.05)$, and by the action stat program. 


\section{Results and discussion}

\subsection{Germination and initial growth test with A. cepa and L. sativa}

During all the seasons (spring, autumn, summer, and winter) the results of the average number of germinated onion seeds (Fig. 2), the average size of roots sprouted (Fig. 3), the percentage, and the speed of onion seeds germination (Table 1) indicated no statistical changes between different points of collection of the Marmeleiro River in the same season. Thus, despite the different uses and occupations of the soil in the river basin, the statistical differences were identified in at least one season of the year for each physicochemical parameter analyzed (Table 2), and the different polluting sources, no difference was observed for A. cepa seeds.

However, the comparison between the same point of collection in different seasons shows that Point 1 , in spring and summer, showed a statistically higher number of germinated seeds (Fig. 2) on the second evaluation day when compared to the same time of autumn and winter. Besides that, this point (Point 1) showed a statistically higher size of roots sprouted (Fig. 3 ) on the third (spring) and fourth (spring and summer) evaluation day. These data can be explained by the higher levels of phosphorus in Point 1 in these seasons (summer: $0.03 \pm 0.01 \mathrm{mg} / \mathrm{L}$ and spring: $0.06 \pm 0.01 \mathrm{mg} / \mathrm{L}$ ) (Table 2), which are even beyond the limits established by CONAMA Resolution no 357/2005 for class II freshwater ( $\leq 0.03 \mathrm{mg} / \mathrm{L}$ ) and statistically different from other seasons for spring. The macronutrients nitrogen, phosphorus, potassium, sulfur, magnesium, and calcium are essential substances to vegetables [21] and, thus, may have stimulated the germination and growth of onion seeds in the present study.

In fact, Point 5 had the lowest phosphorus content in summer $(0.02 \pm 0.01 \mathrm{mg} / \mathrm{L})$, as well as the lowest number of germinated seeds (Fig. 2) on the third and fourth evaluation days. It was different from the same collection point and evaluation days in the spring with the lowest germination rate (Table 1) and the smallest size of germinated radicles (on the third evaluation day) (Fig. 3). It was different from the same point in autumn and spring. Similarly, Point 1 had the smallest size of sprouting radicles on the second day of evaluation in the autumn (Fig. 3), different from the same point of collection and day of evaluation in spring and summer, and had the smallest phosphorus content $(0.01 \pm 0.01 \mathrm{mg} / \mathrm{L})$. Point 4 (summer) had the smallest size of the germinated radicles on the third day of evaluation (Fig. 3), different from the same point and day of evaluation of the other seasons, and had the smallest phosphorus content $(0.03 \pm 0.01 \mathrm{mg} / \mathrm{L})$. So, the phosphorus content is directly related to the germination and growth stimulus of the germinated radicles.

Point 3 presented the lowest number of germinated seeds in the autumn (on the third evaluation day), and the size of the sprouted roots (on the fourth evaluation day) different from the same point and evaluation day of the spring and summer (Fig. 2 and 3). According to the analysis of the physicochemical parameters (Table 2), this collection point (Point 3) had the highest content of chemical oxygen demand in the autumn $(108.56 \pm 16.44 \mathrm{mg} / \mathrm{L})$ (statistically different from other seasons), of oils and greases $(0.24 \pm 0.00 \mathrm{mg} / \mathrm{L})$, and total solids $(600.00 \pm 100.00 \mathrm{mg} / \mathrm{L})$ (statistically different from summer and spring). It was being even beyond the limits established by CONAMA Resolution no $357 / 2005$ for class II of freshwater by oils and greases (virtually absent) and total solids ( $\leq 500 \mathrm{mg} / \mathrm{L}$ ). Point 3 presented the lowest percentage of germination in the winter (Table 1) when compared to the same collection point in the other seasons and the lowest size of the sprouted roots (on the fourth evaluation day) different from the same point and evaluation day of spring and summer (Fig. 3). It also had the second-highest content of oils and greases $(0.17 \pm 0.017 \mathrm{mg} / \mathrm{L})$ and total solids $(553.71 \pm 29.34 \mathrm{mg} / \mathrm{L})$ (also statistically different from summer and spring) even beyond the limits established by CONAMA Resolution. Similarly, Point 6 , in autumn and winter (second and third day) presented the lowest number of germinated seeds (Fig. 2), different from spring and summer, and the highest total solids content (autumn: $633.33 \pm 57.73 \mathrm{mg} / \mathrm{L}$ and winter $606.38 \pm 16.52 \mathrm{mg} / \mathrm{L}$ ), statistically different from summer and spring.

Thus, the data suggest a correlation between water bodies pollution, demonstrated mainly by total solids and oils and greases, and the lower germination and growth of the A. cepa. According to [22], the urban occupation can cause an accumulation of organic matter coming from urban effluents, as shown in Points 3 and 6 in autumn and winter.

This pollution effect may also have influenced the growth of germinated roots (Fig. 3) as Points 2 and 5 (in the autumn) on the second day of evaluation. It presented the smallest size of the germinated roots, the highest levels of chemical oxygen demand (Point 2: $133.00 \pm 3.33 \mathrm{mg} / \mathrm{L}$, Point 5: $88.56 \pm 5.09 \mathrm{mg} / \mathrm{L}$ ), total solids (Point 2: $566.67 \pm 152.75 \mathrm{mg} / \mathrm{L}$, Point 5: $700.00 \pm 100.00 \mathrm{mg} / \mathrm{L})$, and even was statistically different from summer and spring. This effect can also be confirmed for Points $2-4$ in the spring which showed the lowest levels of chemical demand for oxygen (Point 2: $42.68 \pm 0.59 \mathrm{mg} / \mathrm{L}$, Point 3: $44.56 \pm 3.85 \mathrm{mg} / \mathrm{L}$, Point 4 : $51.59 \pm 2.32 \mathrm{mg} / \mathrm{L}$ ), total solids (Point 2: $44.00 \pm 11.53 \mathrm{mg} / \mathrm{L}$, Point 3: $22.00 \pm 12.17 \mathrm{mg} / \mathrm{L}$, Point 4: $10.33 \pm 5.51 \mathrm{mg} / \mathrm{L}$ ), and the largest sizes of germinated roots (on the third and fourth days of evaluation) (Fig. 3). 

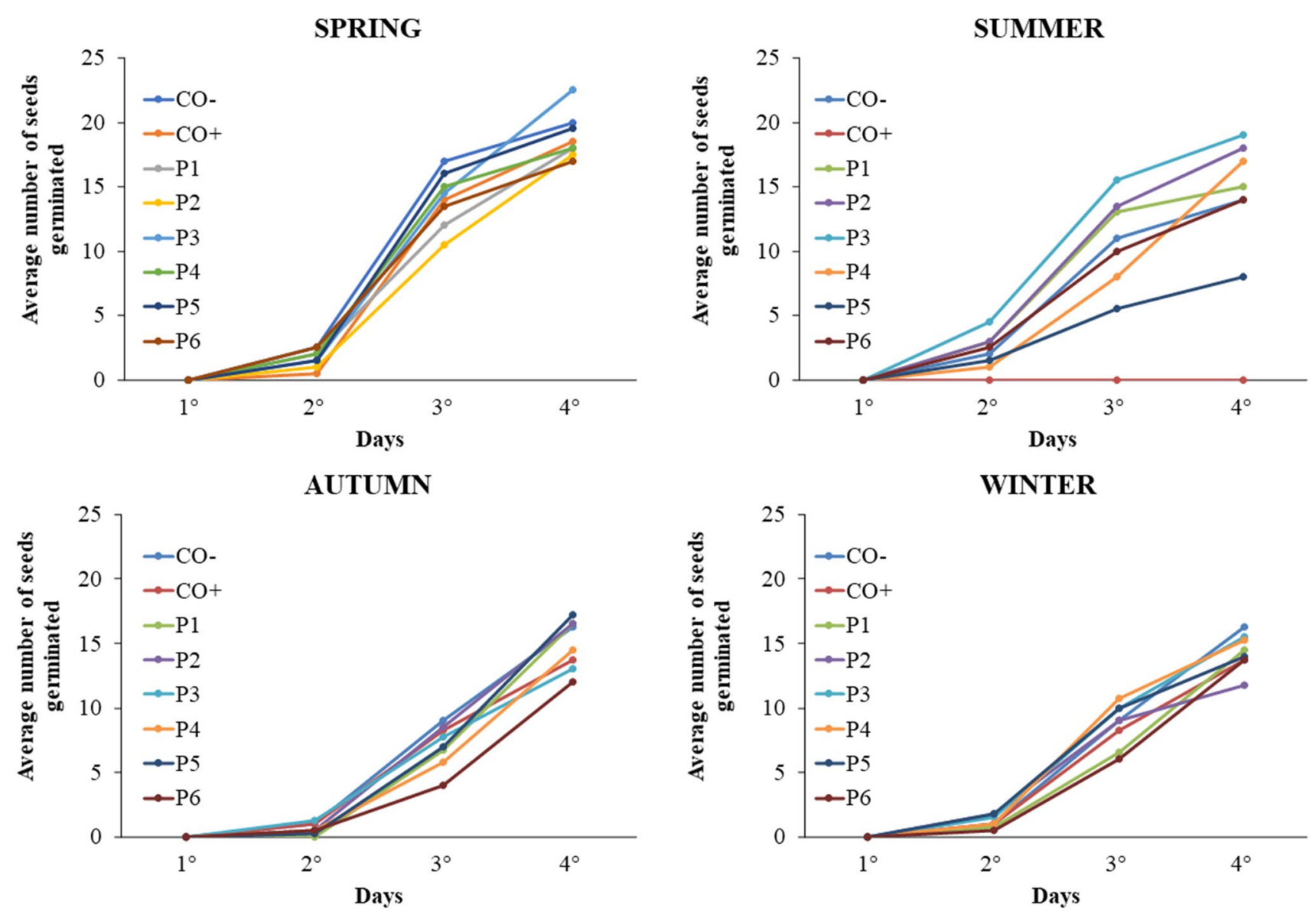

Fig. 2 Average number of germinated A. cepa seeds in the 4-day trial, in the four seasons, for the six points of the Marmeleiro River (Points $\mathrm{P} 1-\mathrm{P} 6)$, and the negative (CO-) and positive $(\mathrm{CO}+)$ controls

Regarding the L. sativa seeds, the number of germinated seeds (Fig. 4) showed that Point 1 (second evaluation day) had a higher number of germinated seeds than the negative control and Points 3 and 5 in the spring. This difference may be related to the presence of agricultural and livestock areas in the river's source. According to [23], the manure is deposited on the soil surface and can be easily dragged to the river, serving as a nutrient to stimulate the germination of the lettuce seeds found in this study. Besides that, as shown for A. cepa, this collection point presented the highest phosphorus $(0.06 \pm 0.01 \mathrm{mg} / \mathrm{L})$ content compared to the other collection points in this station (Table 2). Phosphorus content is related to stimulating germination of seeds, similar to what is shown in A. cepa seeds.

In this sense, Point 3 presented the lowest number of germinated seeds (Fig. 4) and the lowest percentage and germination speed in the spring (Table 1) when compared to the negative control (for the percentage and speed of germination) and to the other collection points, as well as the lowest phosphorus content $(0.01 \pm 0.01 \mathrm{mg} / \mathrm{L})$ among the collection points of this station.
Besides, similar to what was observed with A. cepa, points with a high polluting load showed a lower number of germinated seeds (Fig. 4). This happened with Points 3 (second and third evaluation days) and 5 (second evaluation day) in the autumn, which also had the highest levels of oils and greases (Point 3: $0.24 \pm 0.00 \mathrm{mg} / \mathrm{mL}$ ), according to the higher content of total solids (Point 5: $700.00 \pm 100.00 \mathrm{mg} / \mathrm{L}$ ) and the lower content of dissolved oxygen (Point 3: $5.63 \pm 0.12 \mathrm{mg} / \mathrm{mL}$ ) among the collection points of this station. Point 3 still had a smaller size of the sprouted roots (Fig. 5) in the autumn and Point 4 (on the second and third days of evaluation) showed sprouted roots' size statistically smaller than the negative control and the other collection points, as well as the second-highest total solids content in the winter $(623.98 \pm 26.98 \mathrm{mg} / \mathrm{L})$.

Point 6 presented a number of germinated seeds (spring), size of germinated roots and germination percentage (autumn), and germination speed (summer and autumn) statistically higher than the negative control (for the parameters' percentage and germination speed) and Points 3 and 4 . These results may be due to the fact 

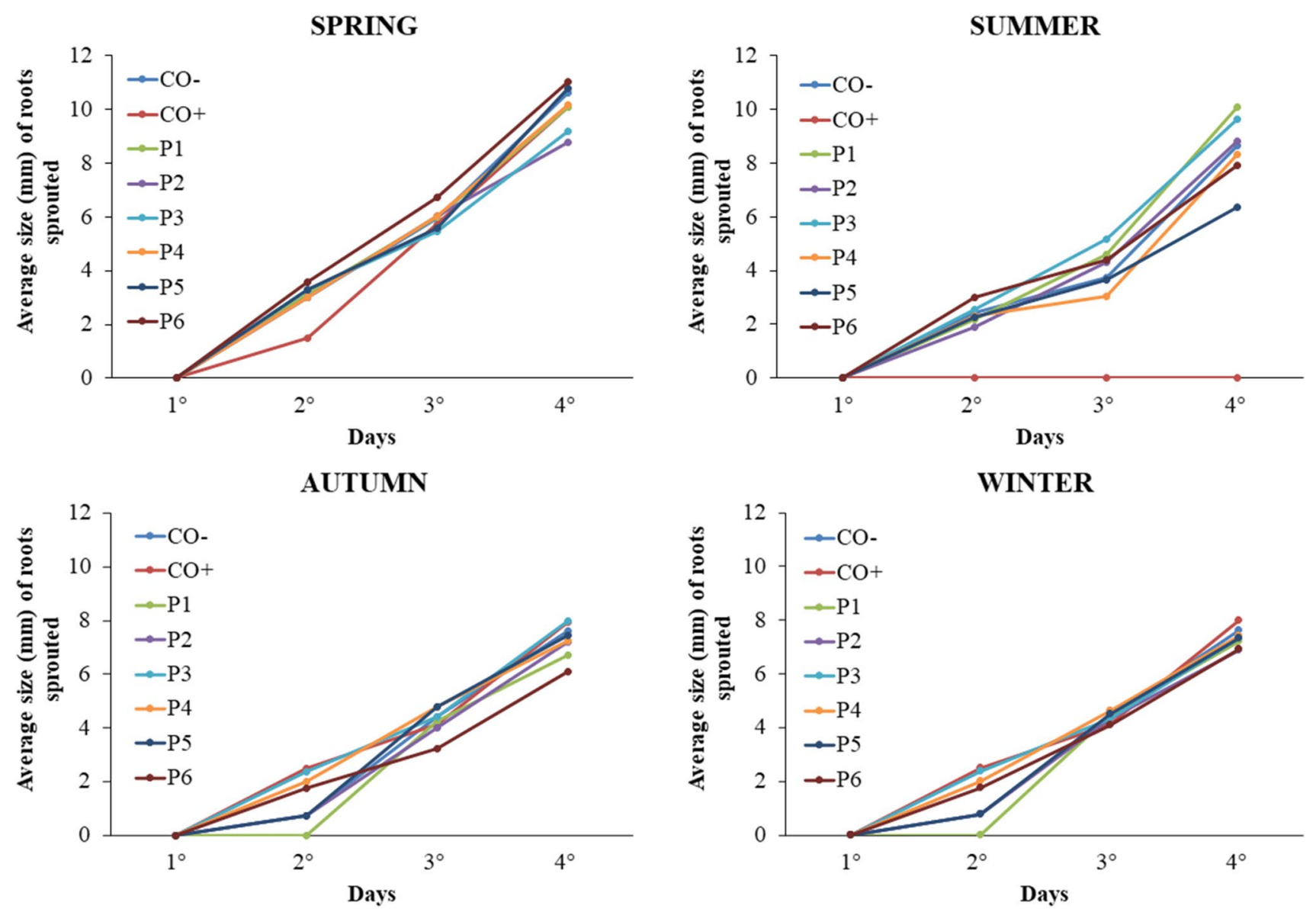

Fig. 3 Average size $(\mathrm{mm})$ of the A. cepa roots sprouted in the 4-day trial, in the four seasons, for the six points of the Marmeleiro River (Points $\mathrm{P} 1-\mathrm{P} 6)$, and the negative $(\mathrm{CO}-)$ and positive $(\mathrm{CO}+)$ controls

that this collection point is located at the mouth of the Marmeleiro River and may contain different substances in its composition, including activities to stimulate the seeds germination and the $L$. sativa roots growth.

It is worth mentioning that, unlike what was observed with $A$. cepa, the experiment with L. sativa showed differences between the collection points and, consequently, the different uses and occupations of the basin's soil and polluting sources. However, only on the fourth day of evaluation, differences between seasons were observed in relation to the number of germinated seeds for the same collection point. In this case, the points of the autumn had the highest number of germinated seeds (Points 1, 5, and 6) and the lowest levels of oils and greases (Table 2) which indicates that the lower water pollution allows greater germination of lettuce seeds. Along with the same line, spring (on the second, third, and fourth days of evaluation) showed an average size of the germinated seeds that was statistically greater than that of the other seasons of the year for all collection points, as well as the lowest levels of chemical demand for oxygen and total solids.
Regarding the percentage and germination speed (Table 1), the collection points in the summer showed the lowest rates (Points 1, 2, 4-6) and germination percentage (Point 1). In general, the points in the autumn had the highest values (Table 1). The analysis of the physicochemical parameters (Table 2) shows that the summer, compared to the other seasons, had the highest (Point 2) and secondhighest (Points 1,5, and 6) contents of oils and greases, and the lowest (Points 4 and 5) and the second-lowest (Points 1-3 and 6) dissolved oxygen levels. In the present study, these parameters indicate water resources pollution and that they can influence the germination of $L$. sativa seeds.

\subsection{Cytotoxicity test with meristematic cells of $A$. cepa}

The results of the mitotic indices average percentages (Fig. 6) show that Point 3 ( $24 \mathrm{~h}$ ) presented a mitotic index statistically higher than the negative control of the group itself ( $\mathrm{P3} O \mathrm{~h}$ ) and its recovery time ( $\mathrm{P3} 48 \mathrm{~h}$ ) (spring), the negative control of the experiment $(\mathrm{CO}-24 \mathrm{~h}$ ) (summer 
Table 1 Germination percentage (PG\%) and speed (SG) of A. cepa and L. sativa seeds in the 4-day trial and the four seasons for the six points of the Marmeleiro River (Points $\mathrm{P} 1-\mathrm{P} 6)$, the negative (CO-) and positive $(\mathrm{CO}+)$ controls

\begin{tabular}{|c|c|c|c|c|c|}
\hline \multirow[t]{2}{*}{ Season } & \multirow[t]{2}{*}{ Points } & \multicolumn{2}{|l|}{ A. сера } & \multicolumn{2}{|l|}{ L. sativa } \\
\hline & & PG\% & SG & PG\% & SG \\
\hline \multirow[t]{8}{*}{ Spring } & $\mathrm{CO}-$ & $80.0 \pm 7.6 \mathrm{Aa}$ & $5.0 \pm 0.5 \mathrm{Aa}$ & $72.8 \pm 3.6 \mathrm{Aab}$ & $4.4 \pm 0.2 \mathrm{Aa}$ \\
\hline & $\mathrm{CO}+$ & $74.0 \pm 8.6 \mathrm{Aa}$ & $4.6 \pm 0.5 \mathrm{Aa}$ & $0 \pm 0 \mathrm{Ba}$ & $0 \pm 0 \mathrm{Ba}$ \\
\hline & $\mathrm{P} 1$ & $72.0 \pm 7.6 \mathrm{Aa}$ & $4.5 \pm 0.5 \mathrm{Aa}$ & $76.0 \pm 3.8 \mathrm{Aab}$ & $3.9 \pm 0.1 \mathrm{Aab}$ \\
\hline & P2 & $70.0 \pm 11.0 \mathrm{Aa}$ & $4.4 \pm 0.7 \mathrm{Aa}$ & $76.0 \pm 3.3 \mathrm{Aa}$ & $4.5 \pm 0,3 \mathrm{Aa}$ \\
\hline & P3 & $90.0 \pm 11.5 \mathrm{Aa}$ & $5.6 \pm 0.7 \mathrm{Aa}$ & $52.8 \pm 2.6 \mathrm{Ca}$ & $3.3 \pm 0.1 \mathrm{Ca}$ \\
\hline & P4 & $72.0 \pm 13.7 \mathrm{Aa}$ & $4.5 \pm 0.8 \mathrm{Aa}$ & $79.2 \pm 4.0 \mathrm{Aa}$ & $4.7 \pm 0.3 \mathrm{Aa}$ \\
\hline & P5 & $78.0 \pm 14.0 \mathrm{Aa}$ & $4.9 \pm 0.9 \mathrm{Aab}$ & $71.2 \pm 3.6 \mathrm{Aab}$ & $3.6 \pm 0.3 \mathrm{Aab}$ \\
\hline & P6 & $68.0 \pm 17.1 \mathrm{Aa}$ & $4.2 \pm 1.0 \mathrm{Aa}$ & $86.4 \pm 4.3 \mathrm{Aa}$ & $4.5 \pm 0.4 \mathrm{Aab}$ \\
\hline \multirow[t]{8}{*}{ Summer } & $\mathrm{CO}-$ & $56.0 \pm 6.0 \mathrm{ABb}$ & $3.5 \pm 0.4 \mathrm{ABb}$ & $64.0 \pm 5.6 \mathrm{Ab}$ & $3.2 \pm 0.3 \mathrm{ACb}$ \\
\hline & $\mathrm{CO}+$ & $0 \pm 0 \mathrm{Ab}$ & $0 \pm 0 \mathrm{Ab}$ & $22.4 \pm 4.5 \mathrm{Bb}$ & $1.1 \pm 0.2 \mathrm{Bb}$ \\
\hline & P1 & $60.0 \pm 33.0 \mathrm{ABa}$ & $3.8 \pm 2.0 \mathrm{ABa}$ & $68.0 \pm 0 \mathrm{Ab}$ & $3.2 \pm 0.3 \mathrm{ACC}$ \\
\hline & P2 & $72.0 \pm 41.7 \mathrm{ABa}$ & $4.5 \pm 2.6 \mathrm{ABa}$ & $64.0 \pm 7.3 \mathrm{Aa}$ & $3.2 \pm 0.3 \mathrm{ACb}$ \\
\hline & P3 & $76.0 \pm 3.7 \mathrm{Ba}$ & $4.7 \pm 0.2 \mathrm{Ba}$ & $60.0 \pm 3.2 \mathrm{Aa}$ & $3.0 \pm 0.2 \mathrm{Aa}$ \\
\hline & P4 & $68.0 \pm 28.7 \mathrm{ABa}$ & $4.2 \pm 1.8 \mathrm{ABa}$ & $63.0 \pm 6.8 \mathrm{Aa}$ & $3.1 \pm 0.3 \mathrm{Ab}$ \\
\hline & P5 & $32.0 \pm 39.0 \mathrm{ABa}$ & $2.0 \pm 2.4 \mathrm{ABa}$ & $57.0 \pm 8.8 \mathrm{ABa}$ & $2.8 \pm 0.4 \mathrm{ACC}$ \\
\hline & P6 & $56.0 \pm 26.0 \mathrm{ABa}$ & $3.5 \pm 1.6 \mathrm{ABa}$ & $66.4 \pm 5.3 \mathrm{Aa}$ & $3.3 \pm 0.3 \mathrm{Cc}$ \\
\hline \multirow[t]{8}{*}{ Autumn } & $\mathrm{CO}-$ & $65.0 \pm 10.0 \mathrm{Aab}$ & $4.0 \pm 0.6 \mathrm{Aab}$ & $78.4 \pm 4.0 \mathrm{ACa}$ & $4.5 \pm 0.5 \mathrm{ACa}$ \\
\hline & $\mathrm{CO}+$ & $55.0 \pm 20.0 \mathrm{Aa}$ & $3.4 \pm 1.2 \mathrm{Aab}$ & $5.6 \pm 0.3 \mathrm{Ba}$ & $0 \pm 0 \mathrm{Ba}$ \\
\hline & P1 & $66.0 \pm 14.0 \mathrm{Aa}$ & $5.8 \pm 1.1 \mathrm{Aa}$ & $85.6 \pm 4.3 \mathrm{ACa}$ & $4.8 \pm 0.6 \mathrm{ACb}$ \\
\hline & P2 & $66.0 \pm 12.4 \mathrm{Aa}$ & $6.4 \pm 1.5 \mathrm{Aa}$ & $76.0 \pm 3.8 \mathrm{ACa}$ & $4.6 \pm 0.3 \mathrm{ACa}$ \\
\hline & P3 & $52.0 \pm 7.3 \mathrm{Aab}$ & $5.5 \pm 0.8 \mathrm{Aa}$ & $72.8 \pm 4.0 \mathrm{Aa}$ & $3.3 \pm 0.2 \mathrm{Aa}$ \\
\hline & P4 & $58.0 \pm 14.8 \mathrm{Aa}$ & $5.2 \pm 1.2 \mathrm{Aa}$ & $76 \pm 5.0 \mathrm{Aa}$ & $4.9 \pm 0.4 \mathrm{Aab}$ \\
\hline & P5 & $69.0 \pm 6.0 \mathrm{Aa}$ & $6.1 \pm 0.7 \mathrm{Ab}$ & $83.2 \pm 4.1 \mathrm{ACb}$ & $4.4 \pm 0.3 \mathrm{ACb}$ \\
\hline & P6 & $48.0 \pm 28.1 \mathrm{Aa}$ & $3.9 \pm 2.2 \mathrm{Aa}$ & $88.8 \pm 6.0 \mathrm{Ca}$ & $5.4 \pm 0.3 \mathrm{Cb}$ \\
\hline \multirow[t]{8}{*}{ Winter } & $\mathrm{CO}-$ & $65.0 \pm 10.0 \mathrm{Aab}$ & $6.5 \pm 0.3 \mathrm{Ac}$ & $70.4 \pm 3.5 \mathrm{Aab}$ & $4.9 \pm 0.3 \mathrm{Aa}$ \\
\hline & $\mathrm{CO}+$ & $55.0 \pm 20 \mathrm{Aa}$ & $5.7 \pm 1.9 \mathrm{Aa}$ & $0 \pm 0 \mathrm{Ba}$ & $0.3 \pm 0.5 \mathrm{Ba}$ \\
\hline & $\mathrm{P} 1$ & $58.0 \pm 9.5 \mathrm{Aa}$ & $5.4 \pm 1.3 \mathrm{Aa}$ & $63.2 \pm 3.2 \mathrm{Aab}$ & $5.3 \pm 0.6 \mathrm{Aac}$ \\
\hline & P2 & $47.0 \pm 17.4 \mathrm{Aa}$ & $5.6 \pm 1.5 \mathrm{Aa}$ & $72.8 \pm 3.6 \mathrm{Aa}$ & $4.3 \pm 0.3 \mathrm{Aa}$ \\
\hline & P3 & $62.0 \pm 18.0 \mathrm{Ab}$ & $6.7 \pm 2.2 \mathrm{Aa}$ & $52.0 \pm 2.6 \mathrm{Aa}$ & $4.2 \pm 0.3 \mathrm{Aa}$ \\
\hline & P4 & $61.0 \pm 10.5 \mathrm{Aa}$ & $6.7 \pm 0.9 \mathrm{Aa}$ & $75.2 \pm 3.8 \mathrm{Aa}$ & $4.4 \pm 0.2 \mathrm{Aab}$ \\
\hline & P5 & $56.0 \pm 22.4 \mathrm{Aa}$ & $6.4 \pm 2.8 \mathrm{Ab}$ & $56.8 \pm 2.9 \mathrm{Aa}$ & $5.2 \pm 0.4 \mathrm{Aac}$ \\
\hline & P6 & $55.0 \pm 21.3 \mathrm{Aa}$ & $5.0 \pm 2.0 \mathrm{Aa}$ & $72.8 \pm 4.0 \mathrm{Aa}$ & $5.7 \pm 0.4 \mathrm{Aac}$ \\
\hline
\end{tabular}

The values with the same letters do not differ statistically among themselves, in uppercase for comparison between points within the same collection season, and in lowercase for comparison between points in different seasons, by Tukey test with a significance level of $5 \%$ and winter), and Points 1 (P1 $24 \mathrm{~h}$ ) (summer) and 2 (P2 $24 \mathrm{~h}$ ) (summer and winter). Point 3 , according to physicochemical analyses (Table 2), presented the second-highest content of chemical oxygen demand $(58.81 \pm 0.92 \mathrm{mg} / \mathrm{L})$ in the winter and the highest content of phosphorus $(0.04 \pm 0.01 \mathrm{mg} / \mathrm{L})$ in the summer. Similarly, [24] also observed that samples with a higher presence of phosphorus promoted a greater stimulation of $A$. cepa cell divisions, possibly because this is fundamental for root growth, similar to that observed in the present study.

Point 4, in spring and winter, had a higher mitotic index and different from the negative control of the group itself (P4 $0 \mathrm{~h}$ ), its recovery time (P4 $48 \mathrm{~h}$ ), the negative control of the experiment (CO-24 h), and of Point 2 (P2 24h) in spring and winter. The physicochemical analyses (Table 2 ) show that Point 4 presented the highest content of chemical oxygen demand in spring and winter when compared to the other collection points of these seasons (spring: $51.59 \pm 0.32 \mathrm{mg} / \mathrm{L}$, winter: $58.86 \pm 0.82 \mathrm{mg} / \mathrm{L}$ ). These results corroborate the work of [25], evaluating the cytotoxicity of the waters of the Quatorze River (Francisco Beltrão, Paraná, Brazil) which also showed that the collection point with the highest chemical oxygen demand was the one that showed a statistical increase in the mitotic index of meristemic cells of $A$. cepa.

These results obtained from Points 3 and 4 of the Marmeleiro River can be justified by the uses of the basin 


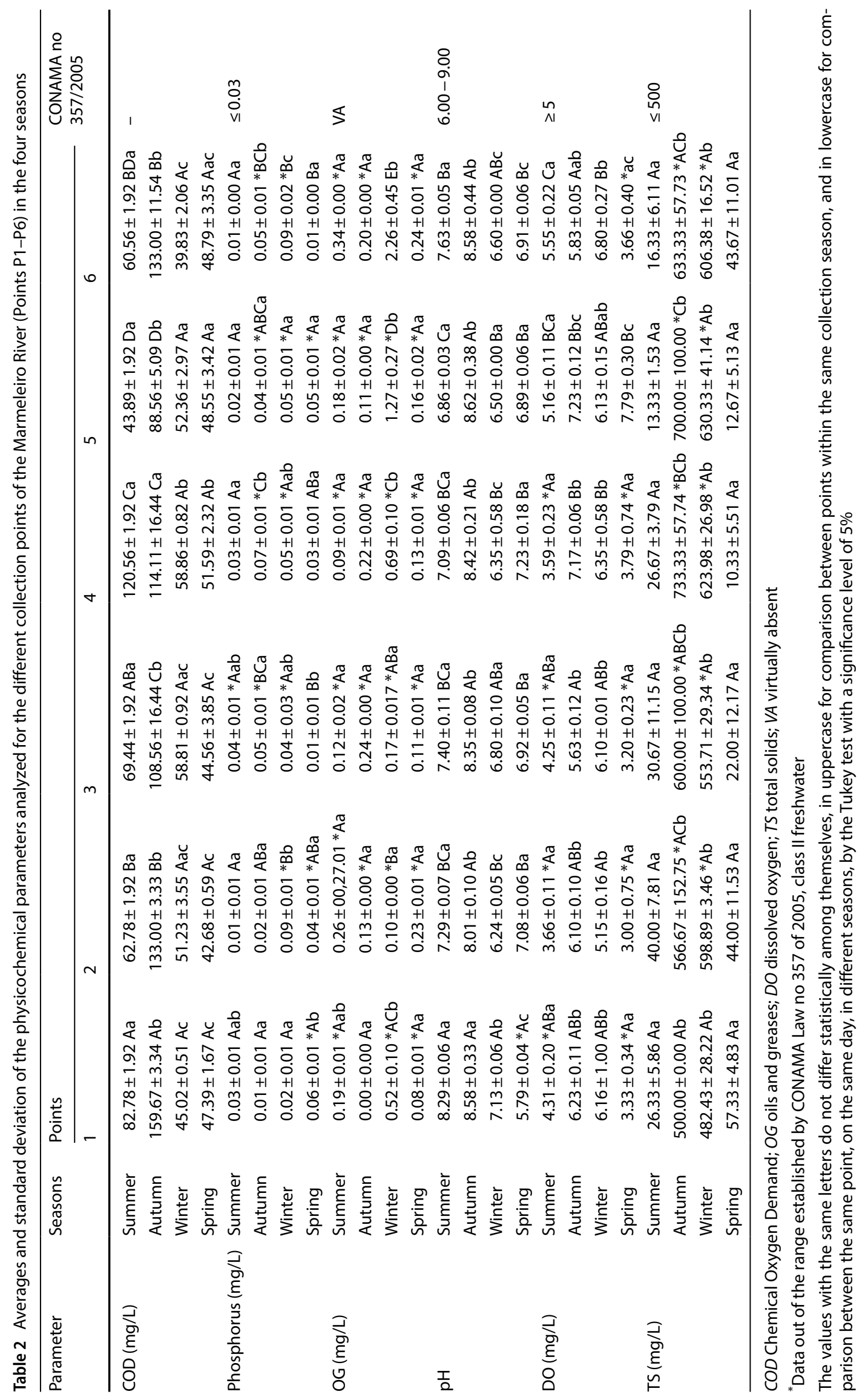



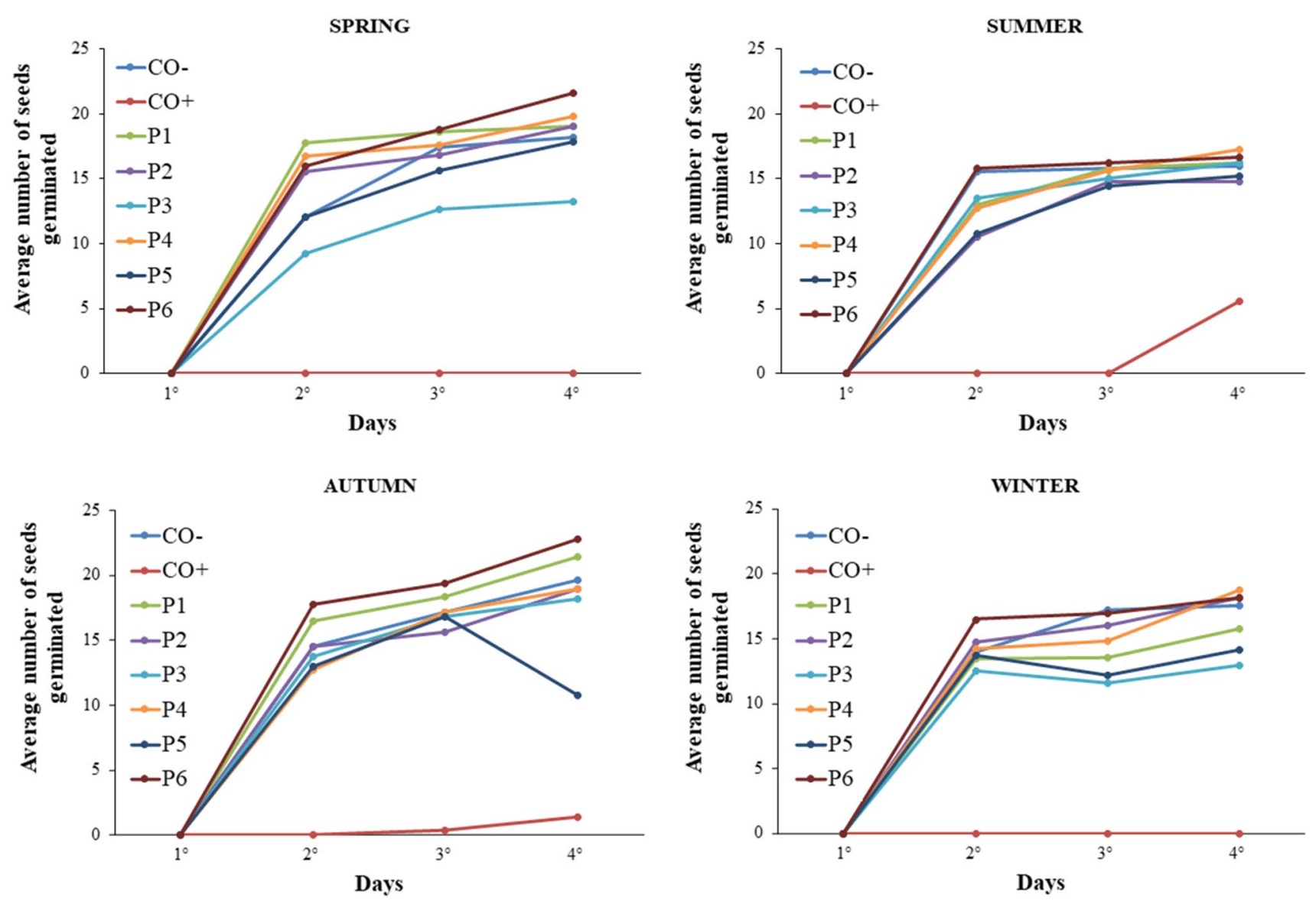

Fig. 4 Average number of germinated L. sativa seeds in the 4-day trial, in the four seasons, for the six points of the Marmeleiro River (Points $\mathrm{P} 1-\mathrm{P} 6)$, and the negative (CO-) and positive $(\mathrm{CO}+)$ controls

in the region of these collection points, predominantly urban, which may have resulted in the carrying of substances with mitogenic capacity to the waters of the Marmeleiro River. According to [22], the urban occupation can cause the accumulation of organic matter coming from urban effluents, and for [7], domestic effluents are rich in organic matter, which may have stimulated the cell divisions of $A$. cepa meristematic cells.

Points 5 and $6(24 \mathrm{~h})$ showed mitotic indices statistically higher than the controls of the bulb itself $(0 \mathrm{~h})$ in summer and autumn, indicating the stimulus of cell proliferation caused by exposure to these water samples. These results show that the regions closest to the mouth of the river (Points 5 and 6) may have accumulated a greater amount of substances with mitogenic potential, which resulted in this stimulus of the cell divisions of A. cepa. However, these points did not differ with the negative control of the experiment or with the other collection points.

\subsection{Immobility/mortality test with $A$. salina}

The data of the immobility/mortality experiment with $A$. salina (Fig. 7) show that all stations had lethality indexes statistically different from the negative control $(C-)$ in at least one point of the Marmeleiro River. According to [26], the use of $A$. salina in toxicity tests is caused by the sensitivity of these organisms.

However, in winter and autumn, only the concentration of $25 \%$ of Point 5 was statistically different from the negative control and the other concentrations evaluated for this collection point. According to the physicochemical data (Table 2), Point 5 was the one with the highest total solids content $(630.33 \pm 1.14 \mathrm{mg} / \mathrm{L})$ in winter and the secondhighest content of this parameter $(700.00 \pm 100.00 \mathrm{mg} / \mathrm{L})$ in the autumn, which may have influenced the result of this toxicity test.

Also, in the autumn, $6.2 \%$ concentration of Point 1 was statistically different from the negative control from the other concentrations evaluated for these collection points and from the same concentrations as in Points 3, 4, and 6 . 

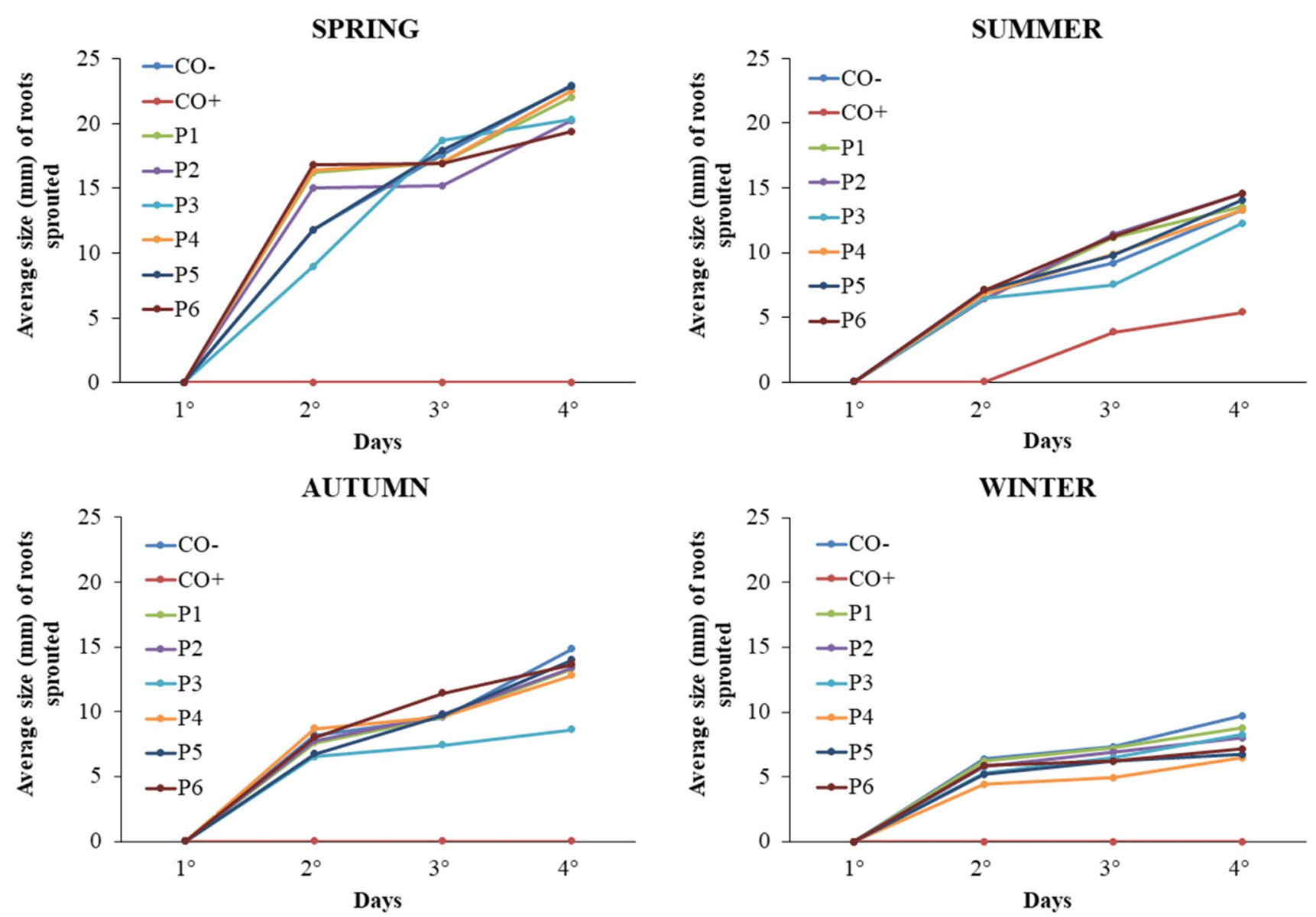

Fig. 5 Average size $(\mathrm{mm})$ of the L. sativa roots sprouted in the 4-day trial, in the four seasons, for the six points of the Marmeleiro River (Points P1-P6), and the negative ( $\mathrm{CO}-$ ) and positive $(\mathrm{CO}+)$ controls

According to the physicochemical analyses, these results may have been caused by pollution at this collection point, identified by the higher chemical oxygen demand at Point $1(159.67 \pm 3.34 \mathrm{mg} / \mathrm{L})$ (statistically higher than the other evaluation points at this station).

In general, the lethality index in autumn and winter was low, where most of the results presented values below $10 \%$, too small values to assume the significant presence of toxicity in the environment on these stations. According to [27], a percentage of mortality under $10 \%$ is insufficient to determine the environmental contamination.

In the spring, almost all concentrations of Points $1-3$ as well as all concentrations of Points 4-6 presented mortality rates statistically higher than that of the negative control. In fact, the comparison between the different concentrations of each collection point between the different seasons of the year shows that spring presented a statistically higher lethality rate than other seasons. These lethality data corroborate to the low levels of dissolved oxygen in these seasons (Table 2), including at several points with values lower than those allowed by CONAMA Resolution
$357 / 2005$ for freshwater class II ( $\geq 5 \mathrm{mg} / \mathrm{L}$ ), where the dissolved oxygen concentration is very important for the survival of aquatic organisms.

It is worth mentioning that for concentrations of $25 \%$ and $50 \%$ (in spring), Points 4-6, in general, showed mortality rates statistically higher than that of the other collection points. These results show that the regions closer to the river mouth (P6) showed high mortality rates because they possibly received an increased discharge of contaminants along the river course.

In the summer, the highest concentration (100\%) of Points 1,4 , and 6 , the concentration of $6.2 \%$ of Point 6 , the concentration of $12.5 \%$ of Point 2 , the concentration of $25 \%$ of Point 3 , and the concentration of $50 \%$ of Point 5 showed mortality rates of $A$. salina statistically higher than that of the negative control and different from the other concentrations of the same evaluated point. Summer presented the lowest levels of dissolved oxygen, showing how it influences the organisms' survival.

Based on tests developed by [28], A. salina showed resistance to the presence of effluents when exposed 

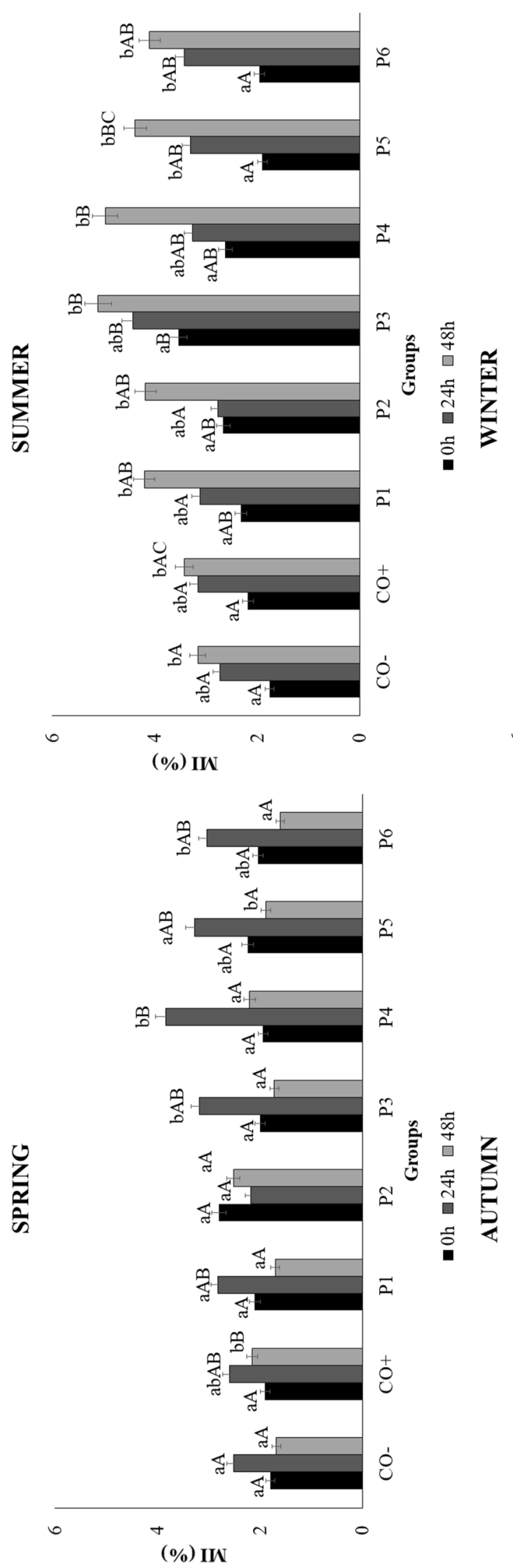

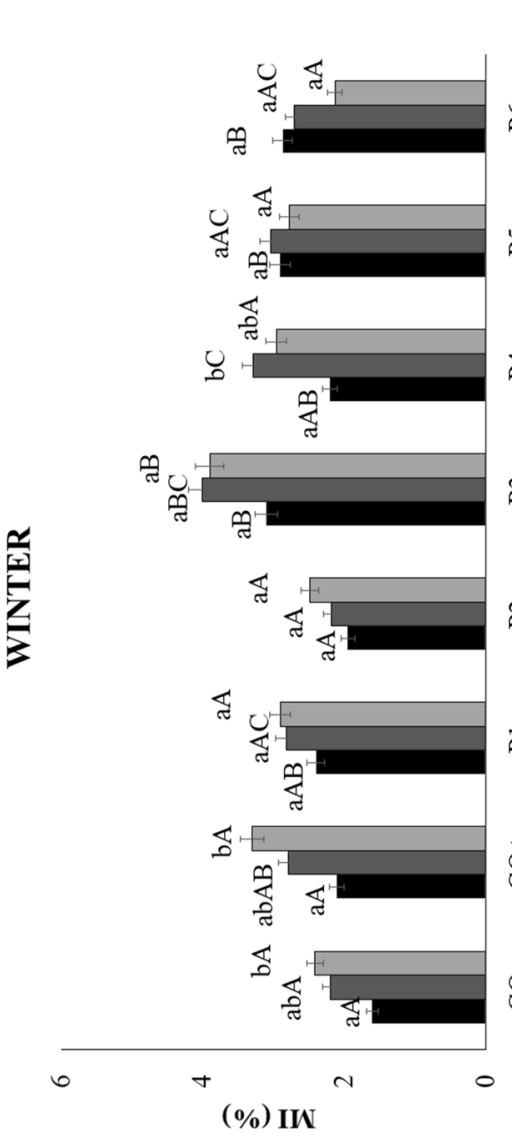

온

离离

$\sum_{0}^{0} \sum_{0}^{\infty}$

둥

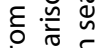

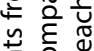

ฉั ㅎํㅇ

웅휴원

銶

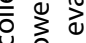

뜨ㄴㅡㅡㅇ 을

$\stackrel{\otimes}{\rightleftarrows} \ddot{\mathrm{x}}$

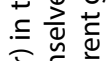

离

उ.

है ते

苧

逜苛

$\frac{\pi}{\pi}$

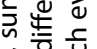

항

흔웡

ᄃ

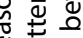

凹一

ᄃ

¿े है

王

宁弯

ᄃ

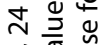

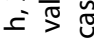

웧

응 을

है월

悹 흥

ᄃ

๙

운

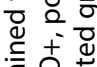

눙

응 훙 힝

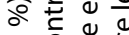

¿ ठํ

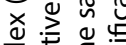

잉

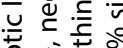

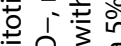

$\sum \circlearrowright$ 证

o $\dot{0}, \underline{E}$

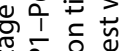

政

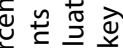

क्षे

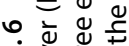

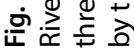




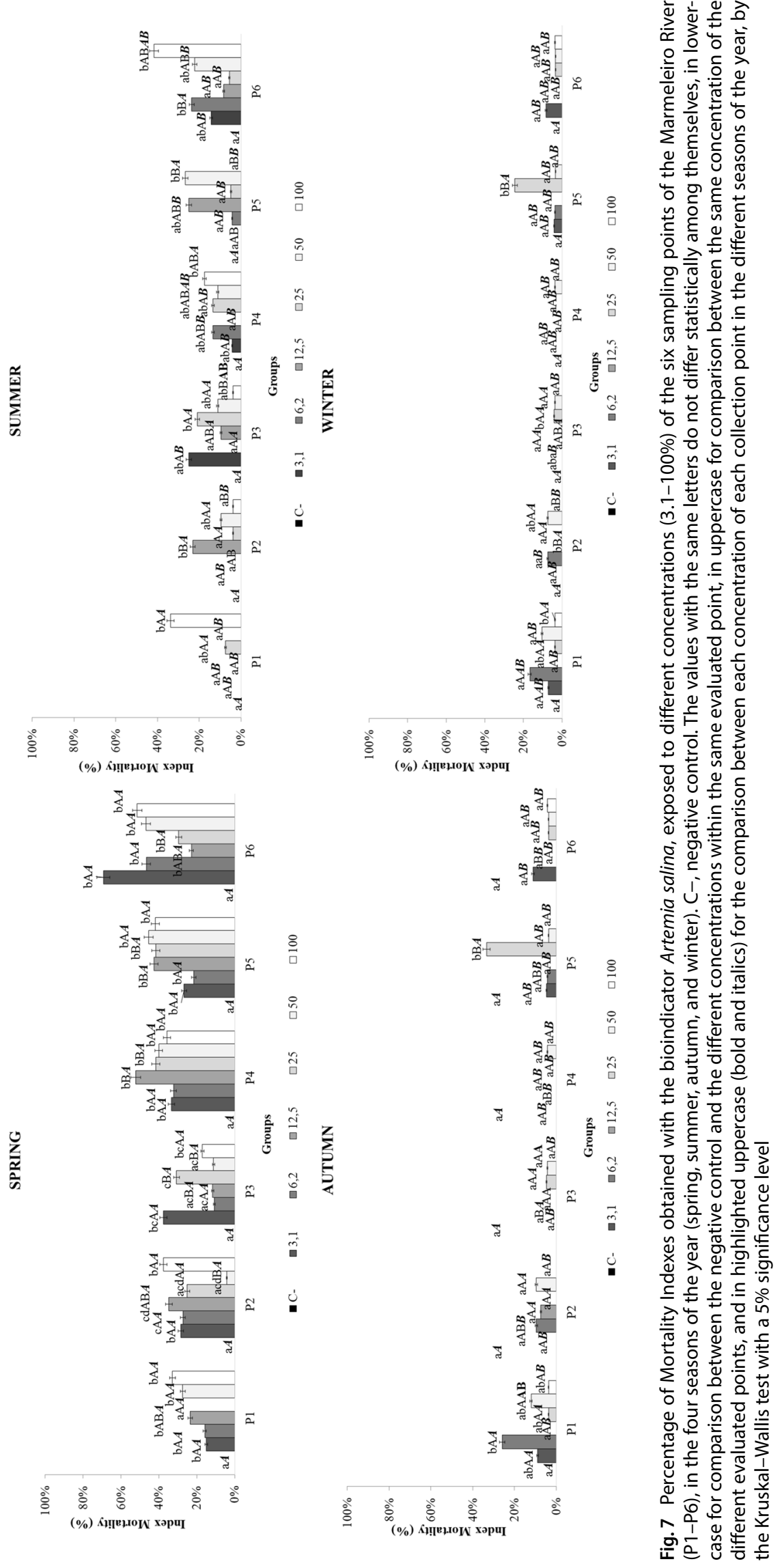


to high concentrations. In the same study, concentrations between 25 and $50 \%$ of the effluent presented a greater frequency of lethality in all seasons, similar to that observed in the present study, in which, in general, the lowest concentrations were toxic.

\section{Conclusion}

In the present study, it was possible to observe that the bioindicators and biomarkers used were efficient to determine and monitor the Marmeleiro River toxicity.

By A. cepa seeds, it was possible to show changes in water quality between stations, with the spring obtaining the highest and best results for the evaluated parameters. However, no difference was observed between the collection points at the same station. Regarding $L$. sativa seeds, the results showed changes in the water quality between the points in the same station and between the same point in different stations, with emphasis on the smaller numbers of germinated seeds, size of germinated roots, percentage, and speed of germination for Points 3 and 6 . And the seasons with the highest values for these parameters were autumn and spring.

In general, regarding the seeds of $A$. cepa and L. sativa, it was possible to correlate the highest numbers of germinated seeds, size of the germinated roots, percentage, and speed of germination with the highest levels of phosphorus in the water samples, as well as the lowest values of these parameters with the highest levels of pollution, determined mainly by the highest levels of chemical demand for oxygen, oils and greases, and total solids.

The results of the cytotoxicity test with A. cepa showed an increase in the mitotic indices of Points 3 (spring, summer, and winter), 4 (spring and winter), 5 and 6 (summer and autumn) correlated with higher levels of phosphorus and chemical oxygen demand in water samples.

Concerning the immobility/mortality test with A. salina, it was observed that the lethality index in autumn and winter was low, but Points 1 (autumn) and 5 (autumn and winter) were toxic for $A$. salina. In spring and summer, at least one concentration assessed from all collection points showed organism mortality higher than that of the negative control, and the spring stood out for having the highest lethality rates when compared to the other seasons. This effect is possibly due to the lower levels of dissolved oxygen in samples from these stations.

The results of the physicochemical analysis showed values above those allowed by Brazilian legislation for phosphorus, oils and greases, $\mathrm{pH}$, dissolved oxygen, and total solids.

Thus, in general, it can be observed that all the collection points had some toxic effect for A. cepa, L. sativa, or $A$. salina showing that the use and occupation of the soil of the Marmeleiro River basin such as inadequate management of agricultural areas, inadequate disposal of waste in the central area of the city, river banks occupation, slaughterhouses, and municipal cemetery are interfering in its quality.

The results show that all seasons of the year presented, for some bioindicators, a more evident toxic effect. Therefore, effective environmental preservation actions must be implemented to protect these water resources and the organisms that depend on them.

This work highlights the importance of environmental monitoring of surface waters and the tests with bioindicators. This research also emphasizes the value of people's awareness regarding the importance to preserve the resources and to prevent water contamination by substances harmful to human and animal health.

Acknowledgements To the Universidade Tecnológica Federal do Paraná and the Environmental Department of the City of Marmeleiro-PR.

\section{Compliance with ethical standards}

Conflict of interest The authors declare no conflict of interest.

\section{References}

1. Shad JJF, Jameel Y, Smith RM, Gabor RS, Brooks WSR (2019) Spatiotemporal variability in water sources controls chemical and physical properties of a semi-arid urban river system. J Am Water Resour Assoc 55(3):591-607

2. Derisio JC (2012) Introdução ao controle de poluição ambiental. Oficina de textos, São Paulo

3. Garcia JM, Mantovani P, Gomes RC, Longo RM, Demanboro AC, Bettin SC (2018) Degradação ambiental e qualidade da água em nascentes de rios urbanos. Soc Nat 30(1):228-254

4. FRAGMAQ (2016) Saiba quais são os tipos de poluição da água. https://www.fragmaq.com.br/blog/saiba-sao-tipos-poluicaoagua/. Accessed 15 Aug 2020

5. Sperling VM (2005) Introdução a qualidade das águas e ao tratamento de esgotos. Editora UFMG, Belo Horizonte

6. Periotto F, Cristina S, Perez JGA, Lima MIS (2004) Efeito alelopático de Andira humilis mart. ex benth na germinação e no crescimento de Lactuca sativa L. e Raphanus sativus L. Acta Bot Bras 18(3):425-430

7. Rodrigues LCA, Barbosa S, Pazin M, Maselli BS, Beijo LA, Kummrow $F$ (2013) Fitotoxicidade e citogenotoxicidade da água e sedimento de córrego urbano em bioensaio com Lactuca sativa. Rev Bras Eng Agrícola Ambient 17(10):1099-1108

8. Bagatini MD, Silva Ferreira AC, Tedesco SB (2007) Uso do sistema teste de Alliumcepa como bioindicador degenotoxicidade de infusões de plantas medicinais. Rev Bras Farmacogn 17(3):444-447

9. Datta D, Singh J, Singh J, Singh S, Singh S (2018) Assessment of genotoxic effects of pesticide and vermicompost treated soil with Allium cepa test. Sustain Environ Res 28:171-178

10. Pimentel MF, Silva Júnior FCG, Santaella ST, Lotufo LVCO (2011) O uso de Artemia sp. como organismo-teste para avaliação da toxicidade das águas residuárias do beneficiamento da castanha 
de caju antes e após tratamento em reator biológico experimental. J Braz Soc Ecotoxicol 6:15-22

11. Luíz AME, Pinto MLC, Scheffer EWO (2012) Parâmetros de cor e turbidez relacionados aos usos do solo e à morfometria da bacia hidrográfica do rio Taquaral, São Mateus do Sul-PR. Rev Caminhos Geogr 24:290-310

12. APHA, AWWA, WEF (1998) Standard methods for the examination of water and wastewater. APHA, Washington, DC

13. ASSOCIAÇÃO BRASILEIRA DE NORMAS TÉCNICAS (ABNT) (1987) Preservação e técnicas de amostragem de efluentes líquidos e corpos receptores: NBR 9898.https://licenciadorambiental.com. br/wp-content/uploads/2015/01/NBR-9.898-Coleta-de-Amost ras.pdf. Accessed 15 Aug 2020

14. IAP (Instituto Ambiental Do Paraná) (2017) Monitoramento da qualidade das águas dos reservatórios do Estado do Paraná no período 2005 a 2008. Editora Fundamento, Paraná

15. Martins BA, Pastorini LH, Roberto BAC (2014) Extratos foliares de Tradescantia zebrina heynh prejudicam a germinação e crescimento inicial de Lactuca sativa L. e Solanum lycopersicum L. Rev Encicl biosf 10:1097-1107

16. Ferreira AG, Aquila MEA (2000) Alelopatia: uma área emergente da ecofisiologia. Rev Bras Fisiol Veg 12:175-204

17. Vieira RD, Carvalho NM (1994) Testes de vigor em sementes. FUNEP, Jaboticabal

18. Fiskesjö G (1985) The Allium test as a standard in environmental monitoring. Hereditas 102:99-112

19. Migliori L, Civitareale C, Brambilla G, Delupis GDD (1997) Toxicity of several important agricultural antibiotics to Artemia. Water Res Water Res 31(7):1801-1806

20. Guerra R (2001) Ecotoxicological and chemical evaluation of phenolic compounds in industrial effluents. Chemosphere 44:1737-1747
21. Kelly J, Unkovich M, Stevens D (2006) Crop nutrition considerations in reclaimed water irrigation systems. Growing crops with reclaimed waste water. Csiro Publishing, Clayton, pp 91-103

22. Andrade AR, Fleuchak IM (2009) A poluição urbana e o impacto na qualidade da água do Rio das Antas-Irati/PR. Rev Eletrônica Curso Geogr 12:01-25

23. Scherer EE, Baldissera IT, Nesi CN (2007) Propriedades químicas de um latossolo vermelho sob plantio direto e adubação com esterco de suínos. Rev Bras Ciclos Solo 31:123-131

24. Silva DCR (2018) Avaliação da ecotoxicidade no solo entorno de uma fonte natural de água pelo teste Allium cepa L. e sua correlação com a presença de resíduos de agrotóxicos.https:// repositorio.roca.utfpr.edu.br/jspui/handle/1/11449Accessed 15 Aug 2020

25. Düsman E, Luzza M, Savegnago L, Lauxen D, Vicentini VEP, Tonial IB, Sauer TP (2014) Allium cepa L. as a bioindicator to measure cytotoxicity of surface water of the Quatorze River, located in Francisco Beltrão, Paraná Brazil. Environ Monit Assess 186:1793-1800

26. Araújo MMS, Nascimento IA (1999) Testes ecotoxicologicos marinhos: analise de sensibilidade. Ecotoxicol Environ Restor 2:41-47

27. Cunha BM (2011) Avaliação ecotoxicológica de distintos tipos de efluentes mediante ensaios de toxicidade aguda utilizando Artemia salina e Lactuva sativa. Dissertation, Federal University of Rio Grande do Sul

28. Oliveira GLS (2013) Avaliação da toxicidade de efluente kraft após tratamento por processos oxidativos avançados. https ://repositorio.roca.utfpr.edu.br/jspui/bitstream/1/1028/1/CT_ COPAM_2012_2_18.pdf. Accessed 15 Aug 2020

Publisher's Note Springer Nature remains neutral with regard to jurisdictional claims in published maps and institutional affiliations. 